\title{
The Rules on Agency Labour in the Labour Legislation of the Russian Federation
}

\author{
Maria Sergeevna Vlasenko \\ Yelets State Bunin University, 399770, Yelets, Lipetsk region, 28 Kommunarov Str., Russian Federation \\ Correspondence: Maria Sergeevna Vlasenko, Department of Civil and Enterprise Law, Institute of Law and Economics \\ Yelets, Lipetsk region, Russian Federation. E-mail: vlasenkomaria@mail.ru
}

Doi:10.5901/mjss.2015.v6n5s4p497

\section{Abstract}

The article refers to the concept new to the Russian labour legislation-agency labour. It examines the problem in legal regulation of the labour contract workers and attempts by the state as part of the solution to this problem regulate legal relations regarding the use of agency labour. The article analyses new to the Russian labour legislation of the Russian Federation rules on agency labour and delivery staff (personnel). The article provides examples of legal regulation of agency labour in some European countries, related to agency labour which recently was negative because of the position of the International Labour Organization, expressed in a number of conventions and recommendations. In the course of the study, such scientific methods as the subject, and specially-legal methods (historical and legal, comparative law) were used. The author distinguishes several periods of agency labour. At the initial stage of the development of agency labour, in Russia there existed ignoring behaviour of the legislator in relation to the agency labour. Then, taking into account the negative consequences for the Russian society, we observed protective options: the negative reaction of the tax authorities, prosecutors and courts to the employment agency workers. Today we can already talk about the combination of adaptive and active variants of behaviour. Based on the study, the author concludes that the meaning of certain provisions of the agency labour needs further interpretation and application of the new rules will not lead to a ban, but to the actual legalization of agency labour through a permitted exception, as it does not appear in principle prohibited by the difference between the borrowing and labour grant temporary provision of personnel. The author sees the new rules a lot of positive things (requirements for accreditation of private employment agencies, the presence of mechanisms to protect the rights, freedoms and legitimate interests of the participants in these relationships).

Keywords: agency labour, legal regulation of agency labour, provision of employees (staff), private employment agencies

\section{Introduction}

Article 37 of the Russian Constitution states that every citizen has the right to freely dispose of their abilities to work, choose the type of activity and profession. With the development of the private business of the citizens there are more employment opportunities, and the growing number of atypical forms of employment. In connection with the adoption of the Federal Law das of May 05, 2014 \# 116-FZ "On Amendments to Certain Legislative Acts of the Russian Federation" ("Collection of the legislation of the Russian Federation", 2014), hereinafter-the Law enters into force on January 01 2016, complemented by a new labour law concept of "agency labour", and a new category of workers, the employer is temporarily sent to other individuals or entities under contract for workers (staff). Agency labour in the world of science is called non-standard form of employment relationship, demonstrating for the past decade, strong growth (Storrie, 2002).

Russia is distinctive with formation of a fundamentally new form of use of human resources, characterized not only by different composition of the subjects of labour relations, but also the fundamental differences between the principal, fundamental interests of employees, employers and entrepreneurs. In this regard, it became possible to study the prospects of legal regulation of new forms of employment. The main objective of this study is to examine the problems of legal regulation of contract labour in the Russian Federation, the development of proposals on improvement of labour legislation.

\subsection{Describe Relevant Scholarship}

Agency labour in Russia is the subject of research of economists, sociologists, labour and civil rights. Comparative legal analysis of regulation of relations on agency labour was devoted to the master's thesis by O. P. Rymkevich (Rymkevich, 2005). International legal, comparative and national aspects of legal regulation of labour considered in candidate's thesis by Y. V. Krivoy (2006). Relations on the use of atypical labour is analysed in the research by A. E. Korkin (Korkin A. E. 
2013). Some aspects of contract labour addressed in doctoral dissertations by V. G. Soifer (2004) and S. H. Dzhioev (2006).

In connection with entering into the labour legislation of the Russian Federation of the rules on agency labour and granting employees (personnel), the topic continues to be particularly relevant in the scientific community, as evidenced by the numerous articles (Kurennoy et al., 2014; Gontsov, 2013).

\section{Method}

The methodological basis are both general scientific and special legal methods: Compilation, analysis and synthesis, the transition from general to specific, historical, legal, comparative legal and other methods of scientific knowledge.

Analysing rules on agency labour and delivery staff made to the Labour Code of the RF and other legislative acts of the Russian Federation, the author comes to the following conclusions. Firstly, the positive sides shall be noted. The legislator aimed to resolve the already established practice of staff, while preventing abuse by employers and protects the labour rights of citizens, the employer is temporarily sent to other persons or entities under contract for workers. To realize this purpose, the Law introduced a number of conditions: accreditation of private employment agencies; payment of the insured, directing their employees temporarily under a contract to provide personnel of insurance premiums from earnings of these workers, based on the insurance rate, as well as premiums and discounts to the insurance rate; the duty of the host to provide information about the results of the policyholder special assessment of working conditions; subsidiary liability for the obligations of the employer arising from employment relationships with employees working under a contract to provide personnel; obligation to ensure that the conditions of remuneration employees sent to work in the host country, is not worse than the conditions of remuneration of persons working in the host organization under the labour contract. Secondly, there is a need for additional interpretation of introduced standards and their revision: for the very concept of agency labour, and the meaning of its ban, the implementation of a mechanism to monitor compliance with the conditions for private employment agencies, the role of trade unions in protecting workers' rights under the contracts for the staff. Without eliminating gaps in the legislation, effectiveness of agreements on the provision of personnel is greatly reduced.

The scientific significance of the study lies in the fact that the developed situation complements existing ideas about the development and content of agency labour relations, problems of legal regulation in the Russian Federation, together with analysis of new aspects of legal problems in the field of agency labour. Conclusions and suggestions made based on the study may contribute to a fuller and deeper understanding of the problems of agency labour, as well as be used in the improvement of the normative legal acts on labour and law enforcement.

Undoubtedly, it is a new concept for the labour legislation of the Russian Federation. But the examples of the use of elements of agency labour in the country's history are numerous. According to A. M. Kurennoy, the mechanism of action of agency labour in the USSR can be seen in the activities of such public organizations as the Human Resources Management of the diplomatic corps who supplied foreign embassies and representative offices of employees, as for their actual employer (Kurennoy, 2007). Since 1990, Russia faces with an emerged problem in legal regulation of the labour for agency workers and attempts by the state as part of the solution to this problem regulate legal relations regarding the use of contract labour and employment agencies appeared. At this stage, agency labour is developing, in such its understanding, which is used by European countries (Vlasenko, 2009). The demand for agency workers in the Russian market was formed solely by enterprises with foreign capital, and since 1998 to overcome the crisis of permanent employees sent on leave "without pay", and in their place for less hiring temporary workers (Zakalyuzhnaya, 2013).

Agency labour needed to be regulated. Based on the international practice of this phenomenon, there are four variants of the behaviour of the legislator in relation to the agency labour:

- Ignoring, expecting to leave the situation unaltered;

- Protective, i.e., aimed at establishing prohibitions in the use of agency labour, increased monitoring and tougher sanctions for violation of the labour and tax laws;

- Adaptive, connected to promoting the positive aspects of this phenomenon, with partial improvement of the legislative framework, the use of the data relationships existing rules;

- Active, i.e., focused on the recognition of the agency labour and the development of special regulation.

Quite recently, relation to agency labour in European countries was negative because of the position of the International Labour Organization, expressed in a number of Conventions and Recommendations (ILO Convention No. 96 "On Paid Employment Agencies", 1949.; ILO Convention No. 88 "On the Employment Service", 1948.; ILO 
Recommendation \# 1" On Unemployment", 1919).

For example, in Germany until the early 70-ies of XX century agency labour was banned. A new stage in the development of agency labour was linked to the decision of the Federal Constitutional Court of Germany on April 4, 1967, which stated that the prohibition of agency labour is inconsistent with the constitutional right to free choice of profession and the ban cannot be justified by the intention to prevent the illicit brokering in hiring. With a view to distinguish agency labour from the private mediation in the labour market, to ensure social protection of workers borrowed in 1972, it was adopted a comprehensive law "On legal regulation of agency labour" (Chesalina, 2012).

At the initial stage of the development of agency labour, in Russia there existed ignoring behaviour of the legislator in relation to the agency labour. At this stage, services of private employment agencies were becoming popular.

Researchers have isolated a number of key trends, specific to the stage of development of the market of private agencies in Russia. Firstly, the expansion (the market of private employment agencies is growing rapidly). For example, the market demand for IT professionals in Moscow exceeded 45 billion roubles by mid-2000. Second, specialization (with the increase in competition, agencies tend to focus their efforts on serving specific market segments). Thirdly, regionalization (development of a regional network is in two ways: opening own offices, as well as the conclusion of franchise or subcontracting) (Losev, 2000).

Then, taking into account the negative consequences for the Russian society, we observed protective options: the negative reaction of the tax authorities, prosecutors and courts to the employment agency workers. Today we can already talk about the combination of adaptive and active variants of behaviour.

As in most countries, employment in Russia through private employment agencies is represented mainly by young workers: $59 \%$ of survey participants are under the age of 30 years, 31\%-31-45 years, and only $10 \%$ are workers over 45 years old. The average age of the Russian agency workers 31 years old, but the age structure is concentrated among 23-26 year olds-is usually the end of the age of vocational education and the first exit to the labour market (Kozina, 2013). The predominance in the composition of agency workforce of young professionals supported by a high level of education of this group of employees, which is the main feature of the Russian agency workforce: $51 \%$ of respondents have higher or incomplete higher education, 25\%-secondary vocational education. The proportion of people with higher and secondary vocational education among agency workers is significantly (by 20\%) higher than the corresponding proportion of the total employed population (Kozina, 2013).

It should be noted that at the time of preparation of the draft rules drawn criticism (Radevich, 2013; Julia \& Alexander, 2014). But the positive thing is that the legislator made the first step in the legal regulation of the staff. The Law, first of all, gives the definition of agency labour. This is labour, carried out by workers on the orders of the employer's interests, under the direction and control of the natural or legal person who is not the employer of the employee (Art. 56.1 of the LC of the RF). Thus the term "agency labour" is not used anywhere else in the Law.

At the same time, in cases prescribed by the Law, it is allowed to carry out activity on providing the labour of the employees, i.e., temporary assignment by the employer of employees with their consent to a natural person or legal entity, who are not the employer of employees for these employees to perform certain of their employment contracts in the interests of labour functions under the control and supervision of the said natural person or legal entity (Art. 1, Art. 341.1 of the LC of the RF).

It is not clear what essentially distinguishes agency labour from those provided by employees. Accordingly, it creates a situation in which the same activity is completely prohibited by some provisions of the Law, and other has limited permits. In fact, the Law on the prohibition of agency labour authorizes the use of agency labour, which creates legal uncertainty, which has been repeatedly emphasized by researchers in the field science of labour law (Salikova, 2014).

The legislator prohibits agency labour. This article of the Law is formulated as a principle and its structure resembles Art. 4 of the LC of the RF: "Forced labour is prohibited. Forced labour is work under the threat of any penalty (violent action)". But, in contrast to the legal characterization of agency labour provided in the Law, the legislator clearly defines what kind of labour related to force labour and what kind of labour is not included in the forced labour. That is, all cases are listed.

With regard to agency labour, then the meaning of the articles of the Law let us conclude that agency labour does not include the performance of the employment contract due to the labour function of the employee, the employer temporarily directed to another person or entity under contract for workers (staff).

Article 341.2 of the LC of the RF, in turn, lists the cases of staff assignment, which is permitted to conclude private employment agency employment contract providing for the direction of the employee to work in the host country under the agreement for workers (staff) are actually in four cases:

1) To be assigned to a physical person, not an individual entrepreneur, for personal services, assistance in 
housekeeping;

2) To be assigned to an individual entrepreneur or legal entity for the temporary duties of absent employees, who retain the work place;

3) To be assigned to an individual entrepreneur or legal entity to carry out work connected with the known time (up to nine months), the expansion of production or volume of services provided;

4) To perform the work in the host country by persons enrolled in full-time education; lonely and having many parents of minor children; persons released from institutions executing the penalty of deprivation of liberty-as in the above three cases, and in other cases where the Labour Code allows entering into fixed-term contracts.

Assignment of employees to work in the host country under the agreement for workers (staff) is not allowed to:

1) Replace workers involved in the strike the host country;

2) Perform works in the case of downtime (temporary suspension of the receiving party work), implementation of bankruptcy proceedings of the host, using of the regime of part-time by the host in order to preserve jobs at threat of mass layoffs in the host country;

3) Replace employees of the host who refuse to work in cases and procedure established by the labour legislation, including the replacement workers, temporarily suspended work due to delayed payment of their wages for more than 15 days.

Along with the above case, assignment of employees by private employment agencies to work in the host country under the agreement for workers (staff) is not allowed in order to:

1) Implement at the facilities assigned in accordance with the legislation of the Russian Federation to the hazardous production facilities of I and II classes of danger, certain types of work, which lists approved in the order established by the Government of the Russian Federation;

2) Perform work at the workplace, working conditions which, in accordance with the legislation of the Russian Federation referred to the harmful working conditions 3 or 4 or dangerous working conditions;

3) Replace certain positions in accordance with the staffing of the host, if the presence of workers, replacing the corresponding positions, is a condition for the host's license or other special permit for certain activities, a condition of membership in a self-regulatory organization or self-regulatory organization issuing the certificate of admission to a certain type of work;

4) Work as crew members of ships and vessels of the mixed (river-sea) type.

The peculiarities of regulation of workers temporarily assigned by the employer to other natural or legal persons under contract for workers (staff), set a new Art. 53.1 of the LC of the RF. The actual composition of any onerous contract of employment includes three elements: promise of activity and compensation and reciprocity of these two obligations. The peculiarities of the employment contract, formulated by L. S. Tahl as an agreement under which one person promises another application of its workforce to his company (farm) as a non-self-employee, following the host authorities and the internal order of the enterprise, for many years made a model legal relationship: "employee-employer". At that, the characteristic feature of the employment contract according to the scientist, was the provision of labour Industrial (economy) for a long period, the subordination of the employee and the internal order of the host government, as well as a promise (obligation) of the employer to pay compensation (Tahl, 2006).

The Law contained a clear notion of the labour contract for workers (staff). This is a contract under which the contractor shall assign their employees temporarily with their consent to the customer to perform these workers of their employment agreements of certain functions in the interests of labour, under the direction and control of the customer, and the customer agrees to pay for services for the provision of workers (personnel) and directed to employ to his employees according to job functions, certain employment contracts concluded by these workers with the performer.

The right to carry out activities to provide labour of the employees (personnel) is given to:

1) Private employment agencies-legal entities registered on the territory of the Russian Federation and been accredited to carry out this type of activity carried out by the authorized federal executive authority in the order established by the Government of the Russian Federation taking into account the opinion of the Russian trilateral commission on regulation of social and labour relations;

2) Other legal entities, including foreign legal entities and their affiliates (other than individuals), under the conditions and in the manner established by federal law, in cases where the employees with their consent to be temporarily assigned to:

- A legal person who is affiliated to the assigning party;

- Legal entity, a joint stock company, unless the assigning party is a party to the shareholders' agreement on the implementation of rights certified by shares of the company;

- A legal entity that is a party to the shareholders' agreement to the parties. 
The Law sets quite high demands on the accreditation of private employment agencies, including the presence of the authorized capital in the amount of not less than 1 million roubles; no arrears in the payment of taxes, fees and other mandatory payments to the budgets of the budgetary system of the Russian Federation; the presence of the head of the private employment agencies in higher education, and work experience in the field of employment or employment promotion in the Russian Federation not less than two years for the last three years; the absence of the head of a private employment agency convicted of committing crimes against persons or crimes in the sphere of economy.

\section{Conclusion}

Agency labour has the same right to legal settlement, as well as other types of atypical employment relations. The legislator went the right way of legal regulation of this phenomenon, albeit with some delay. The Law has many positive features. For example, the absence of a requirement for accreditation of private employment agencies could create risks of abuse of their rights agency that has happened in some European countries (Ratti, 2009). However, the meaning of certain provisions requires interpretation. When sending to another employer, the labour function does not change, but the party changes-the employer, and at the same time employment with the same employer (private employment agency) does not stop. The worker is in two employment relations. But a part-time employee performs two or more works, receives a salary from several employers, provided all kinds of compulsory insurance on each site separately. If one works under a contract for work, the employee performs only one work. In such a situation there is a risk that the application of the new rules will not lead to a ban, but to the actual legalization of agency labour through permitted exceptions, is not seen as the fundamental difference between labour and prohibited by borrowing to allow temporary staff provision.

\section{References}

Borozdna, J. (2014). Alexander Korkin B2B: New Law Bans Temporary Agency Work, But Allows For Secondment. The Moscow Times.

Chesalina, O. V. (2012). Legal regulation of agency labour in Germany. Employment Russia and the European Union: Collection of articles. In. G. S. Skachkova (Ed.), Russian Academy of Science And Law (p. 267). M.: RIOR: INFRA-M,.

Gontsov N. I. (2103). Agency labour in Russia: analysis of some aspects of the theory and practice. Russian Yearbook of labour law (Vol. 9, pp. 208-220).

The International Labour Organization. (1991). ILO Convention No. 88 "On the Employment Service" 1948. Conventions and Recommendations. Geneva.

The International Labour Organization. (1991). ILO Convention No. 96 "On Paid Employment Agencies" 1948. Conventions and Recommendations. Geneva.

The International Labour Organization. (1991). ILO Recommendation \# 1 "On unemployment", 1919. Conventions and Recommendations. Geneva.

Korkin, A. E. (2013). The relationship of atypical use of labour: Concept, types, common issues of legal regulation. Diss. ... of Cand. of Legal Sciences. M.

Kozina, I. M. (2013). Workers of agency labour. Sociological Research, 5, 23.

Krivoy, Y. V. ( 2006). Legal regulation of agency labour: international law, comparative and national aspects. Diss. ... of Cand. of Legal Sciences. M.

Kurennoy, A. M. (2007). Flexibility at work: modern Russian realities. In K. N. Gusov (Ed.), Modern trends in the development of labour law and social security law: Materials of scientific-practical conference (p. 331). M.

Kurennoy, A. et al. (2014). Agency labour: pros and cons. Law, 5, 20-38.

Losev, V. V. (2000). The formation and development of recruitment services market in Russia (p. 3). Author's abstract of ... Cand. of Econ. Sciences. M.

Radevich, E. (2013). Temporary Agency Work and Telework in Russia: Current Issues and Future Developments. E-Journal of International and Comparative Labour Studies, 2(1).

Ratti, L. (2009). Agency work and the idea of dual employership: A comparative perspective. Comparative Labour Law and Policy Journ, 30(4), 855.

Rymkevich, O. P. (2005). Comparative legal analysis of the regulation of the relations of agency labour. Diss. ... of Cand. of Legal Sciences. SPb.

Salikova, N. M. (2014). Agency labour: what does the coming year prepare for us? Business, management and law, 2.

Soiferm, V. G. (2014). Stability and dynamics of the employment relationship. Diss. ... of the Dr. of Legal Sciences. Yekaterinburg.

Storrie, D. (2002). Temporary agency work in the European Union, European Foundation for the improvement of Working life and living Conditions (p.27). Dublin.

Tahl, L. S. (2006). Employment contract. Civil research. M.

Collection of the legislation of the Russian Federation. (2014). The Federal Law as of May 05, 2014 \# 116-FZ "On Amendments to 
Certain Legislative Acts of the Russian Federation".

Collection of the legislation of the Russian Federation. (2002). The Labour Code of the Russian Federation as of Dec 30, 2001 \# 197-FZ

(changes implied by the Federal Laws as of May 05, $2014 \mathrm{~N}$ 116-FZ shall enter into force as of Jan 01, 2016).

Vlasenko, M. S. (2009). Problems of legal regulation of agency labour in Russia (pp. 9-43). Diss. ... of Cand. of Legal Sciences. M.

Zakalyuzhnaya, N. V. (2013). Legal regulation of atypical employment relationship: monograph. Legal company "Contract". 